\title{
Institutional networks for supporting the internationalisation of SMEs: The case of industrial business associations
}

\begin{abstract}
Purpose: This paper aims to study and explore the activities and the use of institutional network resources by industrial business associations (IBAs) to support and facilitate internationalisation processes of small and medium enterprises (SMEs). Other goals are to understand the internationalisation follow-up process and the future vision of IBAs to improve this internationalisation support.
\end{abstract}

Design/methodology/approach: Based on empirical evidence and following an abductive approach, this paper presents a qualitative exploratory field research, providing insights from interviews performed with 20 IBAs based in Portugal.

Findings: Findings suggest that the current institutional network support to internationalisation is mainly provided through: (i) promotional activities; (ii) counselling, training, and technical and legal support; (iii) information sharing; and (iv) cooperation with other institutional entities. Each support category is explored and explained and a new conceptual model is developed to represent these findings. Regarding the internationalisation follow-up, IBAs provide a continuous support for the international operations by using some instruments and mechanisms to assist SMEs after an internationalisation initiative. Finally, collaboration and the use of new information technology (IT) are the main aspects to improve IBAs' support in a near future.

Research limitations/implications: The qualitative methodological approach adopted in this work can imply a larger difficulty to obtain a generalisation of the findings. Another limitation is that the participating IBAs are based in only one country.

Practical implications: Findings can help SMEs to understand the functioning and the benefits of using the institutional network resources of IBAs in overcoming their lack of resources to operate in international markets. IBAs can also understand their current position in terms of internationalisation support and think about new ways for improving this support.

Originality/value: This paper contributes to a better understanding of the influence of institutional networks in SME internationalisation by exploring the specific role of one of the institutional actors, rather than focusing on the institutional network as a whole. Therefore, this study details the current activities and uncovers other types of support provided by IBAs that are not based on export promotion programmes. New knowledge is also obtained about the specific information content, information sources, and means and channels of information sharing used by IBAs for supporting SME internationalisation.

Keywords: international business, internationalisation, small and medium enterprises, industrial business associations, business associations, internationalisation networks, institutional networks, institutional network perspective, internationalisation support. 


\section{Introduction}

The ability to internationalise has become a competitive requirement for the survival of many SMEs, particularly in countries with small domestic markets (Javalgi, Todd, \& Granot, 2011; OECD, 2009). Given their limited resources and difficulties in reaching markets, SMEs tend to rely more extensively on external networks to operate in international markets than large enterprises (Hessels \& Terjesen, 2010). Although current research still emphasises the use of networks by SMEs as a means to support internationalisation (Costa, Soares, \& Sousa, 2016), studies have been predominantly focused on business and social networks, with little attention given to the role of institutional networks (Oparaocha, 2015). Gao et al. (2010) emphasise this lack of attention to institutional networks in International Business (IB).

Different institutional organisations and actors support SMEs in their international activities (Child \& Hsieh, 2014; Gardó et al., 2015) and current research has been performed in contexts such as international entrepreneurship (Oparaocha, 2015), transition economies (Makhmadshoev et al., 2015), and retail internationalisation (Gardó et al., 2015). Findings show that institutional networks have a positive impact on the international strategies of SMEs, mainly by reducing risks and facilitate decisions for expanding into new foreign markets. Still, further developments are needed to increase and deepen the understanding on this phenomenon. In addition, these studies tend to focus on institutional networks in general, without exploring the role of any specific institutional actor. This trend hinders our understanding on the specific activities and ways of support used by each type of institutional actor.

To cover these gaps, this paper aims to elaborate on the institutional network perspective, by exploring the role of industrial business associations (IBAs) in SME internationalisation. Thus, the focus is in one of the institutional actors, rather than the institutional network as a whole. This is the main differencing factor of this work, when compared to previous research. This is based on the assumption that it is fundamental to understand and explore the specific role of each actor that form the institutional network supporting the international activities of SMEs. Such research strategy can allow us to obtain a more comprehensive view and to uncover some specific types of support and activities provided by each institutional actor, as well as to define some points for improvement.

In many EU countries, IBAs have been gaining greater importance for their associate companies, mainly for SMEs, by supporting their internationalisation processes. However, the awareness of public support programmes and the use of institutional networks among SMEs is still low (European Commission, 2010). In addition, both IB and business associations' literature do not either pay much attention to the role of IBAs in internationalisation. This has created false judgments and the wrong assumption that we already know all about the international support provided by business associations, thus explaining this lack of attention. There is no doubts that previous research on public support and export promotion programmes (Freixanet, 2012) can be related with this support from IBAs, as these entities represent export promotion organisations. But there is no clear separation between what business association support is and how it differs from government support. Wilkinson and Brouthers (2006) also conclude that, although identifying and analysing some export promotion activities, future studies need to consider the influence of trade associations and world trade centres for trade promotion. One of the suggestions for future research from Freixanet (2012) is also to discover the differences in terms of impact and assistance requirements of the different export promotion organisations.

Therefore, although identified in previous literature as an institutional actor (Oparaocha, 2015), as an export promotion organisation (Wilkinson \& Brouthers, 2006), or as an information broker for SMEs (L C Leonidou \& Theodosiou, 2004), there is not enough literature to create a good theoretical basis about IBAs, from an IB perspective. This creates an opportunity for extending our understanding on how these organisations are promoting SME internationalisation and how 
they are creating unique value for their members. This study is then guided by the following research question:

RQ: how do industrial business associations obtain and use their institutional network resources to support and facilitate internationalisation processes of SMEs?

Accordingly, based on an institutional network perspective, this paper aims to explore the identified gaps through a qualitative exploratory field research using interviews with 20 IBAs in Portugal. The objective is to first clearly describe and explore what activities those IBAs do and how they obtain and use their institutional network resources to support and facilitate the internationalisation of their members. Institutional network resources are considered in this paper as any kind of resources that institutional actors (in this case IBAs) make available for third parties (in this case SMEs) for supporting specific activities or processes (in this case internationalisation processes), being both internal resources or external resources obtained from institutional network relationships. Another objective is to understand if this support is continuous or if it only remains at some specific stages of internationalisation. Finally, this paper has the purpose of presenting the future vision of the interviewed IBAs, in what regards their future role in supporting SME internationalisation. This future vision includes aspects that can change in a near future, as well as the IBAs' intentions and expected new strategies for best representing future interests of associate SMEs in internationalisation processes.

\section{Theoretical background}

\subsection{Theoretical perspectives of SME internationalisation}

The concept of firm internationalisation can be viewed as the process of increasing involvement in international activities by developing and adapting the firm's inward, outward and cooperative operations to international environments (Lehtinen \& Penttinen, 1999). An internationalisation process can be divided into three phases (Melén, 2009): the pre-firm internationalisation phase, the initial internationalisation phase and the continued internationalisation phase. The pre-firm internationalisation phase includes activities that are performed by key individuals prior to the establishment of a firm and that influence the development of experiential knowledge and personal networks. This phase ends with the establishment of the firm. After that, the initial internationalisation phase begins and consists of the firm's first activities and operations in foreign markets. The third phase of continued internationalisation captures all the activities that occur after a firm's first foreign operations.

The theory of the internationalisation process of large and multinational enterprises (MNEs) has long been developed and discussed in the literature with the behavioural and incremental perspectives (Johanson \& Vahlne, 1977; Luostarinen, 1979). However, as indicated by Knight and Liesch (2016), SMEs are structurally different and behave differently from MNEs, precluding the possibility of theory transferring. MNEs have a highly internalised organisation form (Liesch et al., 2011) while SMEs might invest abroad (not to the extent of MNEs) but opting for more basic forms of internationalisation, such as exporting and other non-equity modes (Lu \& Beamish, 2001). Another distinctive factor of SMEs, when compared with MNEs, is their limited managerial capability, market power, and financial resources, which challenges not only their expansion abroad but also their internationalisation behaviour (OECD, 2009; Olejnik, 2014; Schweizer, 2012).

This distinctiveness of SMEs' internationalisation processes has challenged previously dominant incremental perspectives, attracting the attention of many researchers and resulting in a variety of new research streams. Therefore, although several perspectives, models and theories exist in 
the literature (Wach, 2014), three main theoretical perspectives have influenced research on SME internationalisation: the incremental perspective; the network perspective; and the international entrepreneurship perspective.

In the incremental perspective, Johanson and Vahlne (1977) developed the well-known Uppsala model (U-model), stating that firms gradually internationalise through a series of evolutionary stages, starting with an initial pattern of low commitment involvement into close markets, progressing to higher commitment into more distant markets, as the firm learns and acquires knowledge with its operations. Coviello and McAuley (1999) consider that this incremental perspective, also known as stage approach or behavioural internationalisation process theory, has influenced research on SME internationalisation but many updates have been proposed to illustrate other patterns of firms' internationalisation. Therefore, one of the most important developments is the network perspective, when it became evident that many firms used different networks to facilitate their international activities (Johanson \& Vahlne, 1990). Coviello and McAuley (1999) emphasise the complementary nature between the incremental perspective and network perspective to explain the internationalisation process of SMEs. Thus, following previous findings on the role of networks in internationalisation, a more recent version of the U-model is to consider markets as networks of relationships (Johanson \& Vahlne, 2009). Finally, the international entrepreneurship perspective started to appear, triggered by changes in external environments where firms operate, originating new patterns of internationalisation. Knight and Liesch (2016) confirm that the changes occurred in global markets, allied with the growing technology developments, enabled more firms to internationalise earlier and more rapidly, particularly in the case of smaller ones. The most common terms to identify these kind of firms are international new ventures (INVs) (Oviatt \& McDougall, 1994) and born global firms (BGs) (Knight \& Cavusgil, 1996). This phenomenon showed that some SMEs started their international operations right from inception or soon thereafter, showing inconsistencies with the Uppsala model of internationalisation.

The changes that occurred in international environments now allow companies of any size, age, experience and resources to participate in a more active way in international activities (Knight \& Liesch, 2016). Accordingly, the last update of the Uppsala model tries to include considerations from all these theoretical internationalisation perspectives, leading to the so-called Uppsala globalization process model (Vahlne \& Ivarsson, 2014).

\subsection{Network perspective in SME internationalisation}

The network perspective is one of the most important developments in internationalisation of firms (Johanson \& Vahlne, 1990). Coviello and Munro (1997) highlight the importance of networks in internationalisation of SMEs by suggesting that rapid internationalisation is motivated by formal and informal network relationships, having a vital influence to overcome internationalisation obstacles, thus contributing to SMEs international growth.

Many previous studies were made to explain how SMEs can benefit from their network relationships and which types of resources they can use for internationalisation (Behyan, Mohamad, \& Omar, 2015; Costa, Soares, \& Sousa, 2015). Quite different types of intermediaries can be accessed by SMEs to increase their success in international markets, and many network classifications and typologies have been proposed in the literature. However, the network typology of Oparaocha (2015) was the one adopted for this paper, as it illustrates well the differences and interconnections between three main network types in IB:

- business networks: are the most explored in the literature, representing intermediaries such as suppliers, competitors, strategic partners, and customers; 
- social networks: have also been receiving much attention and are represented by individuals, family, friends, colleagues, and employees;

- institutional networks: not so well explored, with actors including governments, incubators, research institutes, agencies for international development, and business associations.

Castellacci (2014) explains that international business networks and collaborations in service firms are important to foster decisions to enter foreign markets, while Cannone and Ughetto (2014), by studying BGs firms, observe that business network relationships built up by an entrepreneur are one of the key drivers for an early internationalisation and international expansion. Oehme and Bort (2015) also show that, in order to reduce risks, SMEs imitate the internationalisation modes of their peers, based on formal business network relationships.

Regarding the social networks, Xie and Amine (2009) recommend that this kind of networks must be properly recognised as main sources of information, knowledge, and fast learning. Pinho and Pinheiro (2015) describe the importance of using social network analysis as a different methodological approach for understanding the complex social interactions in internationalisation processes of SMEs, and to further contribute to the network perspective in IB. In the case of Ibeh and Kasem (2011), these authors study both business and social relationships in international activities of SMEs. Findings suggest that both types of networks have influence in market entry decisions, but social networks having more influence at initial stages of internationalisation, while business networks gaining more importance at subsequent stages.

According to Oparaocha (2015), there is a lack of studies addressing the role of institutional networks in SME internationalisation. Accordingly, this author makes an important contribution to the institutional network perspective, by examining how institutional networks are influencing international activities of SMEs in the context of international entrepreneurship. Findings show that the institutional networks have a positive impact in the internationalisation of SMEs: (i) by providing important resources, such as market information, financial support, and business contacts, in a continuous way (not only for new entries); (ii) by reducing risks and increasing speed of entries to new foreign markets; and (iii) by leading to a positive attitude towards international entrepreneurship. Some other recent studies also address the institutional network perspective, showing that it allows a more detailed and holistic understanding of the drivers of BGs internationalisation (Kaur \& Sandhu, 2013). Gardó et al. (2015) analyse internationalisation problems faced by Spanish retailer SMEs and also the type of support provided by some institutional organisations. They explain that, although different public and private organisations and agencies that support international activities of firms exist, there is no organisation that specifically targets the retail sector. Therefore, in order to obtain proper international development of retailers, they suggest that those institutional support organisations must provide more support for the SMEs of the sector, as well as to find new ways to better identify their needs in internationalisation.

The previous paragraphs show recent empirical findings about the influence of the three types of networks in the international activities of SMEs. Business networks and social networks have been extensively explored in IB. Consequently, Gao et al. (2010) recommend giving more attention to institutional environments and institutional networks in IB for better understanding its influence on internationalisation of firms. Due to their limited resources, institutional support is of vital importance to SMEs, particularly in the case of internationalisation. While some of the previously identified studies allow for a better understanding on the institutional networks in SME internationalisation, they all recognise the need for more theoretical and empirical insights about this subject. In addition, the tendency is to study general institutional environments without focusing in the specific institutional actors, which creates additional difficulties on understanding how the support differs among each institutional entity. 


\subsection{Business associations}

Globalisation and the development of the European Union (EU) have put pressure on traditional business associations to re-invent themselves, as a way to remain relevant institutional actors in representing the interests of companies and organisations (Streeck et al., 2006). This created a wide range of business associations (Fries, 2008), as well as the rise of a lobbying culture that challenged traditional forms of interest representation in Europe (Grossman \& Woll, 2007). For example, Bennett (1998) and Boléat (2003) present different types of classifications of business and trade associations, which includes associations of companies, legal-based associations, professional associations of individuals, federations and chambers of commerce and industry. The main characteristics of business associations are (Bennett, 1998; Boléat, 2003; Traxler \& Huemer, 2007):

- they are collective and member-based organisations;

- membership is voluntary;

- members have a common interest;

- they are intermediaries between business sectors and state/government action through representation, rulemaking and information;

- they provide services for their members.

The services provided are (Bennett, 1998; Boléat, 2003; Fries, 2008; Mikamo, 2013): government lobbying, newsletters, technical support, information services, conferences and exhibitions, and training. The potential benefits of business associations to governments are an enhanced level of compliance with legislation, as well as lower administrative costs of regulation (Bennett, 1998). In addition, one of the main focus of business associations is to strengthen collaboration among members (Wang \& Gooderham, 2014). In terms of network governance, business associations can be classified as Network Administrative Organisations (Provan \& Kenis, 2008). This means that the flows of control and information are essentially dyadic, centred on the IBA.

However, business associations can also have some limitations, mainly related with problems of low membership and high opting out, instability over time, and inequalities due to the existence of associations of different types or sizes of businesses (Bennett, 1998). Boléat (2003) indicates that many companies have multiple association memberships, both at the individual/staff and business levels. Naturally, this creates some sort of competition environment among the different types of associations. Some governments can also prevent a good functioning of business associations, by creating barriers and political and structural different roles of associations among countries (Fries, 2008).

The main causes that lead companies to join a business association is the desire to exchange ideas for solutions to imminent problems, aiming at their expansion and development, as well as to evaluate their new needs (Boléat, 2003). Other advantages for members of associations are the opportunity to find new business models, to meet new partners and to have support in applying the legislation in force (Traxler \& Huemer, 2007). SMEs and large enterprises clearly differ in their need for services from the business associations. Due to their resource constraints, SMEs are more dependent than large firms on the services, information and contacts generated through business associations (Gashi et al., 2013). Large enterprises can easily make or buy these services independently of associations, and previous research indicates that, in this case, the focus of business associations is mainly on lobbying activities (this does not necessarily mean that those dominated by large firms provide fewer services to their members than the ones focused on SMEs) (Traxler \& Huemer, 2007). 


\subsection{Business associations in SME internationalisation}

Looking at the literature on business associations, there is not much evidence about their specific influence in the international environments of firms. For example, Streeck et al. (2006) focus on the impact of globalisation in the functioning of business associations from both political and sociological perspectives, but without dealing with their role in firms' international activities. Bennett (1998) and Wang and Gooderham (2014) explore the contributions of business associations to the competitiveness of firms, but again, not focusing on IB. In fact, most of the previous studies have focused on policy development and social capital.

\subsubsection{Business associations as institutional actors}

Previous IB literature does neither pay much attention to the role of business associations in international activities of SMEs. Actually, only a few pieces of research address explicitly this link, with a tendency for adopting quantitative approaches. For example, Gashi et al. (2013) investigate the impact of the availability of external financing and membership of business associations on SME export behaviour. They make a quantitative study with SMEs considering many variables (firm size, sector, state ownership, access to external financing, etc.), with the membership of business associations being measured by a dummy variable. Findings suggest a positive influence of membership in business associations to the propensity of SMEs to export, and suggestions for further research are given to create more measures to promote these memberships. Patel-Campillo and DeLessio-Parson (2016) also use a quantitative approach by conducting a survey of Pennsylvania winemakers. Again, many measures are included in this study, where one of the main conclusions is that trade association membership influences both the extent to which geographical branding is adopted by firms and in what forms (if it is regional or state-based). Finally, Costa et al. (2017) give some first insights on the institutional influence of industrial business associations in internationalisation, using a qualitative study and focusing on the perspective of companies (associates/members), from an informational and collaboration standpoint. Findings show mix feelings from companies, i.e. some do not take many advantages from the services provided by IBAs, while others consider that IBAs have capabilities to establish good collaboration conditions between members and that these collaborations have been crucial for their international development.

\subsubsection{Business associations as information brokers}

Other previous studies have looked at information sources to support internationalisation processes of companies, where chambers of commerce and business associations are referred as one of those sources. Regarding the usefulness of the information provided, there are mixed opinions. For example, Leonidou and Theodosiou (2004) conclude that although the experience of chambers of commerce and trade associations offer first-hand information about foreign markets, this information was not extensively used nor regarded as useful by companies. By analysing the information source behaviour of 80 export firms in Cyprus, Leonidou and Katsikeas (1997) demonstrate that companies tend to rely more on personal contacts rather than impersonal sources, such as chambers of commerce and industry associations, when gathering information for internationalisation. In fact, the analysed companies, from one side, recognize the existence of information services from those institutional entities but, from the other side, they often consider to be information of low value. In contrast, Walters $(1996,1993)$ shows that industry associations are considered by companies as a useful information broker to have access to more general, cheap and easy to acquire information about markets and exports (e.g. exports/imports, trade barriers), and to obtain contacts in foreign markets. However, this author also argues that companies also consider that more expensive information sources, with more detailed and market related experience, can be more helpful for their international expansion. 
But the counterpart of using this kind of sources is the intrinsic costs that will limit their use. Riddle and Gillespie (2003) measure the company owners' awareness of the role of two business associations that act as information brokers for SMEs in the Turkish clothing export industry. Results show that these business associations are perceived as very important information brokers for companies' exports, mainly to have access to information about the export laws, foreign markets and the export process.

\subsubsection{Business associations as export promotion organisations}

Business associations are also considered export promotion organisations, which many times overlaps with the export promotion programmes from governments (Wilkinson \& Brouthers, 2006). These programmes are recognised by previous research as having a positive effect in trade promotion, increasing the competitive advantage of both companies in initial export stages and consolidated exporters (Freixanet, 2012). However, the problem remains in the lack of awareness from many companies on the existence of such programmes, which results in its low level of use (European Commission, 2010). In addition to that, it is known that business associations resort to some of those export promotion programmes to support the international operations of their members (Freixanet, 2012). Nevertheless, it is still not clear if these institutional entities use some other ways to give this international support. This is supported by Wilkinson and Brouthers (2006), who despite analysing some export promotion activities, they recognise that other variables warrant more research, such as the influence of trade associations and world trade centres in trade promotion. Moreover, as stated earlier, from other studies on the institutional network perspective of SME internationalisation, it is not clear how the support activities and the related benefits differ among each institutional entity.

\section{Methods}

\subsection{Research design}

This study is an exploratory field research. This approach was chosen as a way to better understand and explore the specific influence of business associations as an institutional network support for the internationalisation of SMEs. Ketokivi and Choi (2014) explain the interplay between theory and practice, in three different research approaches, illustrating their emphasis by the thickness of the arrows, as represented in Figure 3.1: (i) theory generation (inductive research); (ii) theory testing (deductive research); and (iii) theory elaboration (abductive research). 


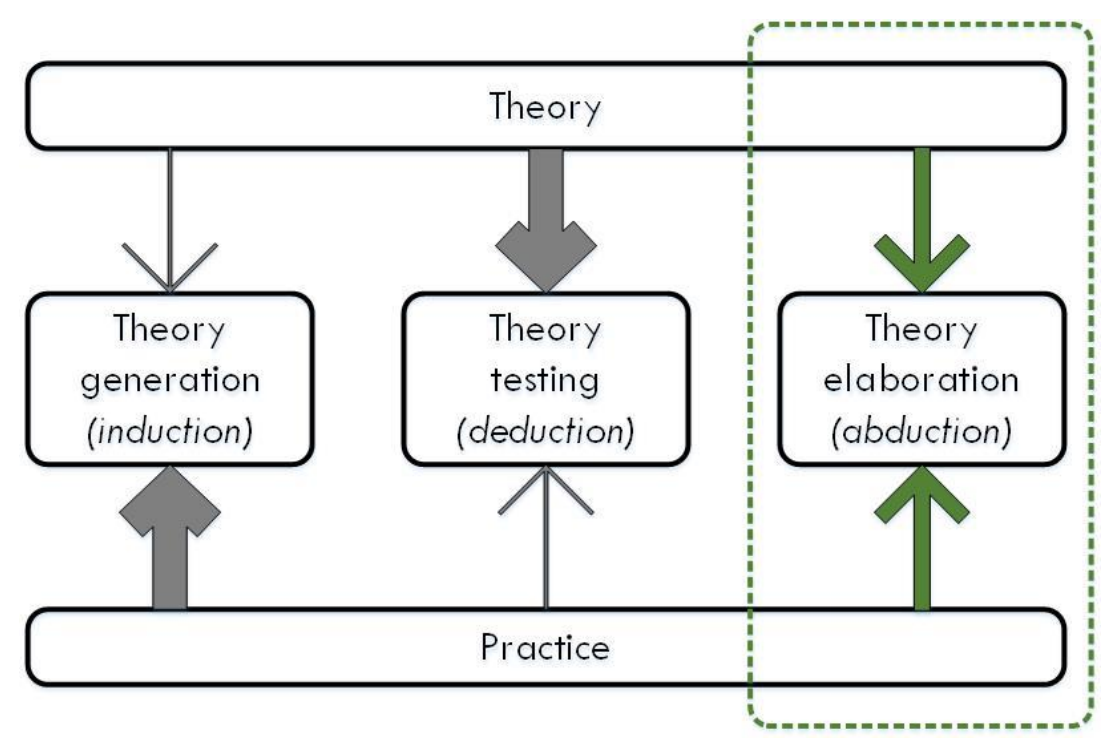

Figure 3.1 - Inductive, deductive and abductive research, and the selected approach (Adapted from Ketokivi and Choi (2014))

This study follows an abductive research approach, as shown in Figure 3.1. Thus, data is collected in a way that allows for theory elaboration. As referred in the previous section, the "network perspective of internationalisation", with specific focus on "institutional networks", provides some of the theoretical foundations for approaching the empirical context (Theory component, in Figure 3.1). However, the context of business associations in SME internationalisation is not sufficiently well known to obtain enough evidences to be used together with these theories, as a way to deduce testable hypotheses or propositions (Practice component, in Figure 3.1). Moreover, other objectives are to conduct an exploratory investigation about this empirical context, and to explore the relationships among concepts (Whetten, 1989), thus challenging existing theories (not only testing them). Theory elaboration also differs from inductive research, as used in theory generation, since some general theories were selected to approach the empirical context.

A qualitative research approach is adopted in this paper to better fit with this exploratoryoriented study. The popularity of qualitative research is continuously growing and spreading across disciplines (Golden-Biddle \& Locke, 2007). The objective of this kind of research is not to generalise the results, but its main value is the specific description, related to the particularity of a specific context (Merriam, 1998; Yin, 2009). A qualitative approach allows researchers to face the complexity, context, and social roles and relationships, of a specific phenomenon (Gummesson, 2006).

\subsection{Research setting and sampling}

The focus of this paper is on national industrial business associations (IBAs), i.e. business associations with a specific focus on industry, representing firms rather than individuals, and with geographical scope at a national level rather than international scope. Accordingly, an IBA is an institutional actor, considered in this paper either as an organisation that represents different firms of a specific industrial sector (sectoral IBA), or as an entity that acts as an intermediary within a multi-sectoral network of industrial companies (multi-sectoral IBA) (Costa et al., 2017). Due to the high diversity of business association types, it is more fruitful to concentrate attentions in one (but broad) type of business association and, in this way, to better conceptualise and make inferences for a higher generalisation of the findings. In fact, it is beyond 
the capacity of one single research project to study the multiplicity of existing business associations in the EU (Traxler \& Huemer, 2007).

The research universe is Portuguese IBAs. There is a wide range of business associations and IBAs in this country. In 2015, the Portuguese business associative system was composed of more than 993 organizations (of which 13 confederations, 39 federations, 10 chambers of commerce and industry, 24 bilateral chambers of commerce and industry, and 907 business associations) (Deloitte, 2015). From this group, $49 \%$ operate at a regional level and the remaining $51 \%$ at a sector level. Due to the small domestic market of Portugal, many SMEs have been struggling to face the competitive pressures, and internationalisation becomes a necessary step for their survival. However, although representing $99 \%$ of the total number of enterprises in Portugal, only a small percentage of SMEs are actively involved in international operations (Banco de Portugal, 2015).

A theoretical sampling strategy was used to select the cases for this exploratory study, allowing for a theoretical replication logic (Corbin \& Strauss, 2015; Eisenhardt, 1989; Yin, 2009). The selection procedure started with the identification of possible IBAs best fitting the established criteria: (i) associations focused on one or more industrial sectors rather than focusing on business in general or rather than associations only focused on legal issues; (ii) business associations representing mostly firms rather than individuals; (iii) national business associations rather than international federations and associations; and (iv) business associations with a high number of associate members (more than 30 associate companies). The last criteria was considered as a way to obtain a sample with enough sector representativeness. This screening led to a list of about 100 Portuguese IBAs from different industrial sectors. After this initial screening phase, 20 IBAs were selected for the study, from three main cities/regions of this country: Lisbon, Porto and the Minho region. The sample was large enough to reach theoretical saturation (Corbin \& Strauss, 2015; Eisenhardt, 1989) and to obtain a good analysis on the use of institutional network resources from IBAs to support SME internationalisation. Most of the cases are sectoral IBAs, and 5 IBAs are multi-sectoral. Table 3.1 shows the main information about the 20 selected IBAs.

Table 3.1 - Main information about the selected IBAs

\begin{tabular}{|c|c|c|c|c|c|}
\hline ID & Industry sector & Members & $\begin{array}{l}\text { No. of } \\
\text { interviewees }\end{array}$ & $\begin{array}{l}\text { Position of the } \\
\text { interviewee(s) }\end{array}$ & $\begin{array}{l}\text { Duration of the } \\
\text { interview ( } \mathrm{min} \text { ) }\end{array}$ \\
\hline IBA1 & Automotive & 70 & 1 & Technical Secretary & 72 \\
\hline IBA2 & Construction & 7000 & 3 & $\begin{array}{l}\text { Secretary-general; } \\
\text { Economist; Board Advisor }\end{array}$ & 52 \\
\hline IBA3 & Metals & 900 & 1 & $\begin{array}{l}\text { Internationalisation Project } \\
\text { Manager }\end{array}$ & 46 \\
\hline IBA4 & Wood and furniture & 700 & 1 & Director & 40 \\
\hline IBA5 & Food & 400 & 1 & General Coordinator & 61 \\
\hline IBA6 & $\begin{array}{l}\text { Metallurgical and } \\
\text { electromechanical }\end{array}$ & 500 & 1 & General Director & 54 \\
\hline IBA7 & $\begin{array}{l}\text { Electrical } \\
\text { electronic }\end{array}$ & 90 & 1 & $\begin{array}{l}\text { Economics and Association } \\
\text { Service }\end{array}$ & 43 \\
\hline IBA8 & Cork & 270 & 1 & General Director & 63 \\
\hline IBA9 & Chemicals & 40 & 1 & General Director & 18 \\
\hline IBA10 & Footwear & 400 & 2 & CEO; Project Manager & 71 \\
\hline IBA11 & Furniture & 200 & 1 & $\begin{array}{l}\text { Marketer- } \\
\text { internationalisation }\end{array}$ & 49 \\
\hline IBA12 & Mining & 200 & 2 & $\begin{array}{l}\text { Director of Communication } \\
\text { and Advice for } \\
\text { International Relations; }\end{array}$ & 45 \\
\hline
\end{tabular}




\begin{tabular}{|c|c|c|c|c|c|c|}
\hline & & & & & $\begin{array}{l}\text { CFO and International } \\
\text { Relations }\end{array}$ & \\
\hline IBA13 & Multisector & & 800 & 1 & $\begin{array}{l}\text { Director of International } \\
\text { Relations Department }\end{array}$ & 52 \\
\hline IBA14 & Multisector & & 100 & 1 & $\begin{array}{l}\text { Secretary-general and } \\
\text { Director of International } \\
\text { Relations }\end{array}$ & 49 \\
\hline IBA15 & $\begin{array}{l}\text { Defence } \\
\text { weaponry }\end{array}$ & and & 70 & 1 & General Director & 44 \\
\hline IBA16 & Aerospace & & 40 & 1 & General Executive Manager & 66 \\
\hline IBA17 & Multisector & & 280 & 3 & $\begin{array}{l}\text { President of the } \\
\text { Administrative Council; } \\
\text { Board Administrator; } \\
\text { Technical Administrator }\end{array}$ & 39 \\
\hline IBA18 & Agro food & & 130 & 1 & $\begin{array}{l}\text { Executive Coordinator of } \\
\text { Markets Division }\end{array}$ & 54 \\
\hline IBA19 & Multisector & & 370 & 1 & Project Manager & 49 \\
\hline IBA20 & Multisector & & 2000 & 1 & Information Manager & 36 \\
\hline
\end{tabular}

\subsection{Data collection and data analysis}

Data collection was based primarily on semi-structured interviews, with IBAs' managers and people involved in international activities in IBAs. Additionally, some official documentation and information from IBAs' websites was also used as secondary sources for data triangulation (Yin, 2009). At the beginning of each interview, participants were asked to sign an informed consent document, showing their knowledge about the purpose of the study, as well as to confirm whether they allowed the interview to be recorded for accuracy purposes. For this study, all participants allowed the audio recording of the interviews. The interviews had durations between 18 to 72 minutes, with an average of 50 minutes per interview, in a total of over 16 hours of recordings. Only one interview (IBA9) had a duration of less than 30 minutes (i.e. 18 minutes) because during this interview, the interviewers realised that the IBA did not have much experience in supporting internationalisation, and consequently, there would be no point in asking some of the subsequent questions. Nevertheless, this case was kept in the sample, to understand in which areas this internationalisation support was made, and to allow the discover of some other interesting issues, such as their needs and requirements to be able to give more international trade support to their members. Appendix 1 presents the questions and the interview guide of this study. Due to the exploratory nature of this study, some additional questions were asked in some interviews, to clarify and complement our understanding regarding some specific aspects.

The interviews were transcribed as soon as possible, to ensure a constant comparison (Eisenhardt \& Graebner, 2007) but also for a first analysis, and for the improvement of subsequent interviews (Corbin \& Strauss, 2015). These transcriptions were made using the qualitative data analysis software MAXQDA. After the transcriptions, the interviews were coded, using again the MAXQDA software, allowing an extraction of the relevant results and insights from the interviewees. At this stage, IBAs' documentation was also used for data triangulation (Yin, 2009). Using the saturation technique (Eisenhardt, 1989), data was coded and analysed until sound results were achieved.

The analytic cycle of qualitative data analysis was used to help developing theory from empirical data (Bendassolli, 2013), the cycle consisting of data coding, categorising, and conceptualising processes. Therefore, the data analysis started with an initial contact with the interviews' transcripts by a general reading, followed by a more careful reading. During this stage, notes 
were taken through an initial memoing (Corbin \& Strauss, 2015) to record impressions and insights and to let emerge categories that facilitated later stages of the analysis. The second stage of data analysis was performed using within-case and cross-case analysis (Barratt et al., 2011; Eisenhardt, 1989). Therefore, the coding procedure was complemented by clustering themes and codes into categories, as a way to develop conceptualisations (Bendassolli, 2013). This step was important to understand the main differences between each of the IBAs under analysis. To facilitate the operationalisation of the concepts, visual concept mapping was also performed using the knowledge-modelling software Cmap (Wheeldon \& Faubert, 2009), to develop conceptual maps showing categories from theory and new emerging categories from the analysis. Therefore, themes and patterns were identified using an abductive reasoning, this leading to a mix between inductive research (allowing some themes to emerge from the data) and deductive research (relying on some other themes from the "institutional network perspective of internationalisation" theory). The last stage of data analysis was performed by: (i) contrasting the findings with the network perspective of internationalisation, and with other relevant findings in the literature; (ii) contextualising the findings and developing conceptual maps to encompass a wider picture about the institutional network influence of IBAs in SME internationalisation.

Some validity and reliability procedures were also considered, such as using documents and information from the IBAs' websites for data triangulation (Yin, 2009), using a diversity of informants for a more complete vision of the environment and for guarantying the construct validity (Mark Barratt \& Barratt, 2011), and using a study protocol to repeat the data collection procedures, ensuring the reliability of the study (Yin, 2009).

\section{Findings}

\subsection{Current institutional network support}

This section presents the empirical findings from the interviewed IBAs, regarding their current role and the use of institutional network resources to support their associate SMEs. Four main categories related to internationalisation support were identified based on the interviews' transcripts, notes from the research team, and IBAs' documentation. These categories are briefly conceptualised in Table 4.1, and then discussed in further detail in the following subsections.

Table 4.1 - Conceptualisation of the main categories of IBAs' internationalisation support

\begin{tabular}{ll}
\hline Category & Conceptualisation \\
\hline Promotional activities & $\begin{array}{l}\text { In the case of internationalisation, IBAs promote the following initiatives that help SMEs } \\
\text { in their international promotional activities: trade fairs; trade missions; promotional } \\
\text { actions; events, meetings and collaborative workspaces. }\end{array}$ \\
$\begin{array}{l}\text { Counselling, training, } \\
\begin{array}{l}\text { and technical and } \\
\text { legal support }\end{array}\end{array}$ & $\begin{array}{l}\text { IBAs have an important counselling and training role for supporting SME } \\
\text { operate within the laws and rules of foreign countries. Some technical support is also } \\
\text { provided for research and development (R\&D) and internationalisation projects. }\end{array}$ \\
$\begin{array}{l}\text { Information sharing } \\
\text { Different types of information are shared in IBAs to support SME internationalisation, } \\
\text { such as market opportunities, market conditions, legal information, business contacts, } \\
\text { initiatives and other relevant information according to each industrial sector. This } \\
\text { information comes from a vast diversity of information sources and is shared by different } \\
\text { mean and channels, such as email, websites, social networks, personal contact and } \\
\text { journals/magazines. } \\
\text { IBAs act as intermediaries and cooperate with a vast variety of other institutional actors } \\
\text { to provide the necessary information, contacts and conditions to the international } \\
\text { activities of their associate SMEs. The identified cooperative entities are governments, }\end{array}$ \\
$\begin{array}{l}\text { Cooperation } \\
\text { other institutional } \\
\text { entities }\end{array} \quad$\begin{tabular}{l} 
with \\
\hline
\end{tabular}
\end{tabular}




\subsubsection{IBAs as export promotion organisations}

\section{Promotional activities}

Trade fairs are one of the main initiatives promoted by IBAs to support the internationalisation of SMEs. In these fairs, SMEs create moments of interaction and relationships with potential clients and, in many cases, they even establish important collaborations with other companies.

"...in the case of trade fairs, we use an event manager that visits the companies and presents them the project. This event manager is responsible for doing a turnkey service, i.e. he accompanies the company from the moment of the expression of interest to go to a specific trade fair or market, until the organisation of travels, visas, stand renting, reservation of the space for the fair, hiring round trip transportation to take the products, stand decoration, etc." (IBA4)

IBAs also mention other types of R\&D and internationalisation projects that help SMEs in their internationalisation processes, such as developing digital platforms to support internationalisation and promoting the companies and the sector in different ways. These promotional actions can result from an IBA representing the sector in trade fairs and events, to bring the message to the markets and to the clients.

"What we have been doing, with much effort and budget, is to communicate the sector in a more macro-perspective... and all this logic of communicating the sector is mostly made by us... What is required by companies is for the association to make a broader communication and promotion of the sector... In recent years, it is no longer requested for the association to organize a trade fair... or to organize a trade mission." (IBA8)

IBA10 mentions that contacting journalists and the press is another interesting way of communicating their sector. IBA18 organises promotional actions in hotels, with product exhibitors, and meetings between companies and buyers of a particular foreign market.

Trade missions and reverse trade missions are another internationalisation support pillar, considered fundamental by the interviewees. The first of these types of initiative consists of going with the associates to foreign markets of interest, allowing the associates to know new countries, to understand the functioning and the dynamics of foreign markets, and to make commercial contacts for their international activities.

"There is always the concern to ensure the contact between companies that are already in certain markets (usually large companies) and companies that we take to the missions, encouraging the establishment of these contacts locally in the country of destination." (IBA2)

Reverse trade missions consist of bringing foreign companies and entities, who are looking for new clients and suppliers, to meet the Portuguese players and visit their facilities. The trade fairs, trade missions and promotional actions are mainly funded by the government or other specific national and European projects, through export promotion programs. IBAs apply to this projects system that allows companies to have reduced participation costs.

Finally, the IBAs of this study also promote different kinds of events and meetings to strengthen the collaboration, between associates, and between associates and potential partners. IBA2 and IBA3, for example, promote internal sessions where companies share their experiences with 
other associates, about previous trade missions and fairs. IBA8 promotes meetings, where companies give inputs to the IBA on how and where they should be working. Many other types of meetings and events are organised by IBAs, thus creating collaborative workspaces for associate SMEs, such as seminars, committees, working groups, and round table discussions, for sharing and obtaining knowledge about international opportunities or other key points for their internationalisation.

\section{Counselling, training, and technical and legal support}

Findings also point to counselling and training as another relevant SME internationalisation support from IBAs. Some IBAs organise workshops in the labour and tax areas, about foreign markets where the companies intend to internationalise. IBA3 has an "academy of internationalisation", where professionals in IB give lectures to companies that are starting their internationalisation process. This training is mainly focused on marketing, trade fairs, credit insurance and transportation. In the case of IBA6, individual and group training is provided, for the participating members to learn how to outline an international strategy. The IBA makes a full diagnosis of each company and prepares the company for its international expansion.

"...and one of the areas is internationalisation, see what is missing, how to prepare that company, what are the markets that may be of interest (one or two), how the company should restructure itself to have a sector linked with sales, with marketing, having catalogues, having a website to give visibility to the company, knowing languages, etc." (IBA6)

The interview with IBA11 stresses the counselling and training role of the association. This IBA interacts with its members since their initial internationalisation process and helps both companies that are starting and companies already with some international experience. Companies starting these processes are trained to face the reality of international markets (identifying the best market, product typology, and event), to identify possible partners, and to contact more experienced members, in order to share past experiences and know-how. For the more experienced companies, besides information and experience sharing, the IBA supports them in finding new markets or helps them to remain in already settled ones.

Findings also suggest that IBAs provide an essential legal support and counselling for their associates. This support mainly involves sharing the legislative changes, the commercial changes in markets, tax information, and entities that act as intermediaries for the demanding regulation and legislation in foreign countries. The main concern of IBA9 in terms of internationalisation is to defend the interests of companies at an international level, mainly regarding the European legislation. Thus, their role is essentially played in Brussels, through European associations of the sector. Finally, the IBA14 federation participates in the definition of the internationalisation support policies, and advises the Government on those public policies. Their main role here is to develop European political partnerships, by informing their associates about international trade agreements and bilateral agreements, as well as by negotiating the reduction of trade barriers and the reduction of all types of barriers, to allow the access to markets.

Some of the interviewed IBAs also distinguish another type of initiative, the technical support and incentive for SMEs to participate in international projects. IBA7 and IBA16 are examples of associations that act as promoters or facilitators, and collaborate with some of their associate SMEs in making joint applications for international R\&D projects. In some cases, and due to competitive issues, companies push the IBA to be the consortium leader, as in most cases the IBA represents all the involved partners, and it has no direct commercial interest in the initiative. 


\subsubsection{IBAs as information brokers}

Another fundamental support for the international operations of SMEs is the information that is shared by IBAs. Many of IBAs in this study perform market studies and reports for their members, in order to better know the foreign markets regarding industrial sectors, trends, opportunities, legal issues, and key players in each market of interest. These market studies can be performed either by the associations themselves or by gathering the information from international studies performed by others. Naturally, the dissemination of the initiatives promoted by IBAs is another relevant information content for the associate companies.

"...we generate some market information, studies that we do, we gather legal information, commercial changes in markets, etc. so, generating and sharing this information with the associates." (IBA8)

As stated earlier, some IBAs were able to develop digital platforms, each with a specific purpose to support internationalisation. In cooperation with international associations and other institutional entities in Portuguese-speaking countries, IBA6 was able to create a tool that supports companies in getting information about those countries regarding legal aspects, tax information, conditions to create a company, industrial areas, and other useful information for an adequate international expansion. IBA13 created a platform for supporting large companies in subcontracting SMEs for specific international operations. In the case of IBA20, a digital platform was developed to aggregate different types of information about each associate individually, thus increasing its visibility for potentially interested foreign companies and organisations.

"...we give support with a range of business information that can help the companies to define their internationalisation strategy... we have access to a set of databases with information about foreign companies that can help entrepreneurs to make decisions... We share market studies about foreign countries and we also often share information about effective and concrete companies that are abroad." (IBA20)

Some associations, such as IBA6, also perform important survey studies, and build databases on both internal associates and industrial companies in foreign markets. This type of information, together with information about calls for international projects or other opportunities, are most of the times shared by IBAs, using their websites or even their digital platforms. IBA17 emphasises the fact that being present in international and European organisations allows them to have access to valuable information about norms, policies and guidelines, which is also important for the international expansion of companies. Based on all the information provided by IBAs, companies can make better decisions and can establish more effective internationalisation strategies.

Therefore, there are several topics within the internationalisation area and the information content depend on the theme and target that a member wants to achieve. Table 4.2 summarises the main information content derived from the interviews.

Table 4.2 - Main information content shared by IBAs to support SME internationalisation Information content

- Statistical data of the industrial sector, such as:

- evolution of the sector;

- exports/imports by country;

- number of companies in a specific country; 
o main foreign importers.

- News and information about the industrial sector, such as:

- about national and international companies of the industrial sector;

- success stories;

○ events.

- Opportunities for internationalisation

- Legislative changes

- Regulatory and political aspects, such as:

○ international trade agreements;

○ analysis of international trade agreements;

- analysis of bilateral agreements;

- agreements between the European Union and other countries.

- Information about promotional actions, such as:

- trade fairs;

- trade missions;

- events and exhibitions;

- calendar of actions;

- detail of each action (dates, location, requirements, costs).

- Visits of potential clients

- Information about specific companies (national and foreign companies)

- Contacts in national and international markets

- Information about training activities:
- workshops;
- seminars;
o other training actions.

- Information of opportunities about applications for national and European projects:
○ deadlines;
- requirements;
o benefits;
o costs.

- Information from own market studies, such as:
- new trends;
- key players in markets;
○ how the market works;
- credit insurance;
- market data and financing conditions.

- Information from own databases:
- companies' characterization;
○ products that export;
- countries of exports;
- product labels and product details;
- practiced prices.

The main means and channels to share this information to their members are: email (the most used); telephone; social networks (mainly Facebook and Linkedln); personal contact (visits to members, meetings, events, etc.); IBAs' websites; books, journals and magazines; newsletters; the press and media; other digital platforms and portals. 


\subsubsection{IBAs as cooperative institutional actors}

The influence of IBAs in SME internationalisation can also be measured by the vast number of contacts and cooperation agreements that are established with other national and international entities. As referred, these entities provide important contacts and information for IBAs to be shared with associate companies. The main cooperative actors mentioned in the interviewees are governments, foreign associations and IBAs, and the External Trade and Investment Agency of Portugal (AICEP). Due to its vast knowledge and experience in the area, this agency is viewed by many interviewees as being crucial if a company wants to have a successful international expansion.

"...AICEP and its delegations give much support and also support the process. AICEP has been instrumental in all this" (IBA6)

"The first information source normally on the market is the local office of AICEP." (IBA10)

"AICEP has very relevant information online, exporter guides... it has delegates in several countries and therefore locally, AICEP is obviously in a privileged situation to have this information on potential partners" (IBA14)

Other relevant institutional connections and cooperative protocols are often established with entities such as embassies and chambers of commerce and industry, as a way to obtain other specific information about market conditions, barriers and business opportunities. IBAs themselves are often members of international associations and agencies of different types, this clearly increasing the chances of establishing new contacts, sharing experiences and obtaining relevant information (see above) for their associate companies.

"The association is part of various international institutions, in which it has contact with other European clusters and by being in contact with these clusters, it can identify opportunities much easier than companies would do it per se." (IBA16)

Finally, findings suggest that IBAs act as an important intermediary for SME internationalisation, by cooperating with many other entities and by using different information sources that allows them to have a rich amount of contacts and information to be shared with their members. Table 4.3 synthesises the cooperating entities and the information sources used by IBAs to support SME internationalisation, divided by internal and external sources. 
Table 4.3 - Information sources used by IBAs to support SME internationalisation

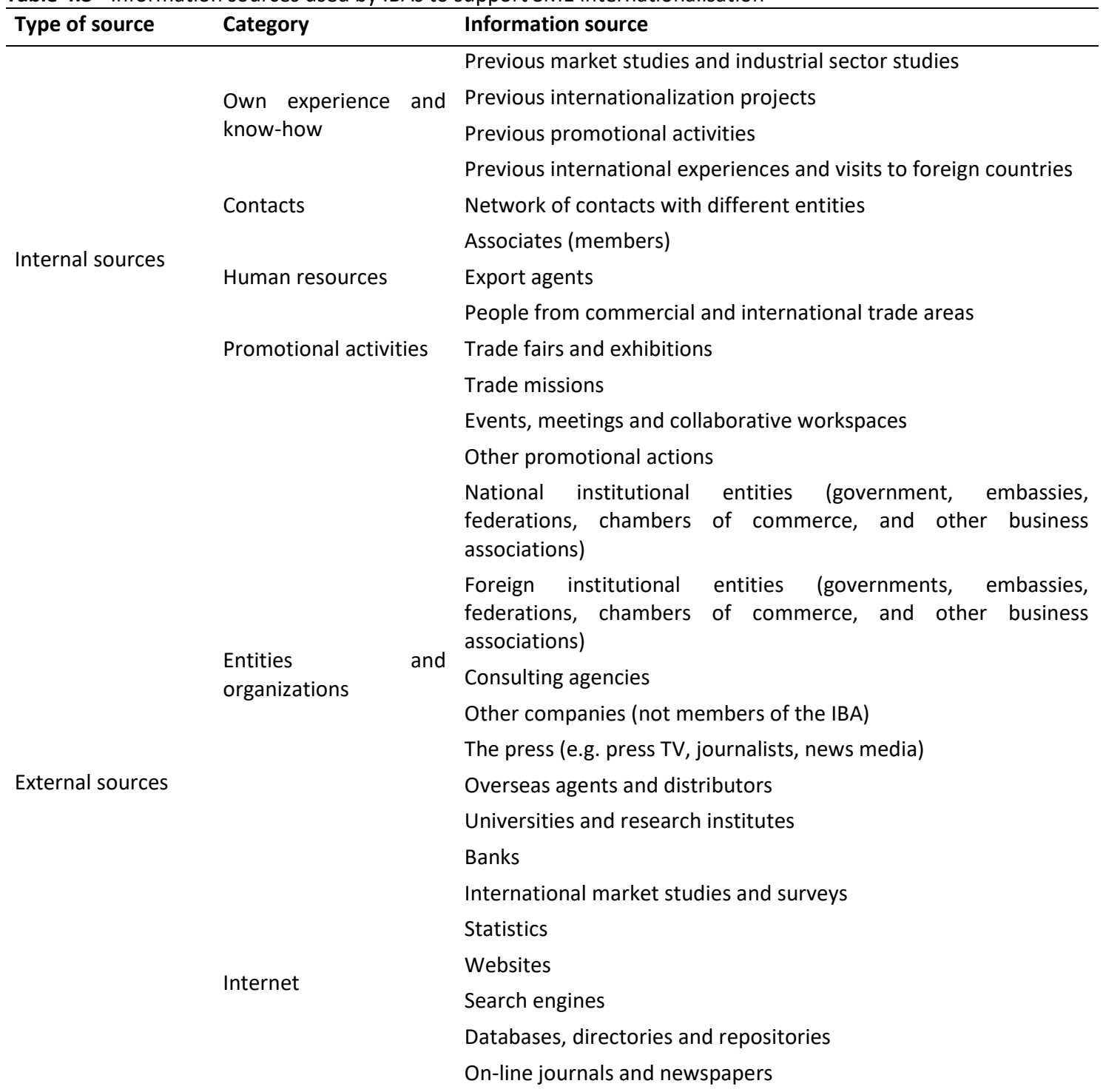

The IBAs' network of contacts is referred as one of the most important information sources. Most of them have many established and trusted contacts that comes from decades of experience, acquired in previous studies and internationalisation projects. So, the own experience and know-how is a vital information source for the IBAs. A particular case to highlight here is the specific IBAs' members that often serve as a relevant information source. These members express not only their needs to the IBAs but also indicate some specific countries that can be of interest for the exportations of the sector, or even some specific internationalisation projects and opportunities. What they expect in return is for the IBA to use its contacts, services and knowledge base, and to act as intermediary between them and entities of interest. The use of databases is also mentioned by the interviewees, but only some of them are actually using this data source because it has high costs of acquisition. Some particular entities and organisations are also mentioned by the interviewees as being relevant important sources of information about international trade and activities:

- International sources:

- European Commission; Horizon 2020; OECD (Organization for Economic Cooperation and Development); WTO (World Trade Organization); BusinessEurope (confederation of European business), nTrade (statistics).

- National sources: 

agency of Portugal), INE (national institute of statistics), Republic Diary and Assembly of the Republic (for more legal information), IAPMEI (public agency for competitiveness and innovation), Bank of Portugal, and Portugal 2020 (a partnership agreement between Portugal and the European Commission that provides funding opportunities for the Portuguese business).

\subsection{Internationalisation follow-up}

Another objective of this study is to understand how IBAs follow-up the internationalisation process of their associate SMEs. Findings show that most of the interviewed IBAs provide a continuous support for the international operations of SMEs. Many of the interviewees send surveys to their members to know if they had success in some specific initiative promoted by the IBAs. In these surveys, SMEs are inquired about the benefit of participating in the initiative, the contacts that were obtained, and the concretised internationalisation opportunities. Such instruments are important for IBAs to send reports and indicators of the initiatives promoted to the funding institutions. There are surveys for each action, and annual surveys to have a global perspective for each internationalisation year. However, many companies do not respond to these surveys, creating difficulties to the IBAs' perception of the success or failure of their initiatives.

"We try to get feedback, it's not always easy. There is an instrument that we use which is a questionnaire and many of the companies do not respond. But it's something we try to do it two weeks after a specific initiative... but it does not work. And it does not work because people are busy doing the follow-up of the initiative, and the results do not appear right after." (IBA18)

Nevertheless, IBAs suggest other ways of accompanying the internationalisation of their members. Quite often, the feedback is obtained through personal contact in future initiatives, or by a contact from the companies if things are going wrong, "If there is silence it's because everything is fine". IBA6 asks the export volume of their associate SMEs to understand whether it has increased. In the case of IBA10 and IBA12, both the interviewees explain that they can obtain feedback on their support, based for example on the continuous participation of SMEs in trade fairs and missions promoted by them.

"The editions of the trade fairs are held most of the times by semesters, which means that if they participated in a trade fair and if they did not participate in the next, in principle it is because it has no interest. That is, the increase or decrease of participations in the next edition, end up giving us some feedback on whether the fair is progressing well or badly." (IBA10)

The internationalisation follow-up from IBAs is normally performed by providing more information and new contacts about markets of interest, not only for exports but also for more complex internationalisation strategies.

"In more complex internationalisation processes, we can give more support with our contacts and we have better ways of minimizing risks, which is what matters to companies... So, the company is supported by who has the right contacts and the experience. This is our added value to the companies." (IBA13)

Finally, the interviewee from IBA10 states that they have mechanisms to help and assist SMEs after an internationalisation initiative, in the sense of collecting and providing new information, or trying to mobilise local agents to help them to solve some specific problems or barriers. 


\subsection{Future vision}

Finally, we report on the vision and perspective of the interviewed IBAs, regarding their future role in supporting SME internationalisation. In general, IBAs expect that their support to the international activities of their members will improve in a near future, and that new strategies are planned to achieve this improvement. Many IBAs recognise that the organisation of trade fairs and missions will continue to be part of their support strategy. However, the interviewees also acknowledge that with new market dynamics and with constant developments in technology, the adoption of new approaches is crucial to remain an active support to SME internationalisation. The interviews showed that IBAs want to implement different strategies, and what they think it is important to achieve. Table 4.4 presents a summary of the most important focal points and the new strategies that are planned in the future to support internationalisation.

Table 4.4 - Future vision about the IBAs' support to SME internationalisation

\begin{tabular}{ll}
\hline Strategy & Detail \\
\hline $\begin{array}{l}\text { Collaboration } \\
\text { cluster }\end{array}$ & $\begin{array}{l}\text { IBA1 will participate in the creation of a collaboration cluster for the sector, together with } \\
\text { entities such as companies, other business associations, universities, research institutes, } \\
\text { technological centres, and consultancy companies. The internationalisation of SMEs will be one } \\
\text { of the main topics to be addressed, in order to improve those processes through a cluster } \\
\text { dynamic and collaborative way. The final aim will be to improve the competitiveness of } \\
\text { companies and promote exports. The IBA will also create contacts and links between the } \\
\text { partners, to form consortiums for applying to new research projects on internationalisation. }\end{array}$
\end{tabular}

Digital platform IBA2 will start to use a digital platform for grouping companies in collaborative networks. The IBA will try to systematise the information about markets in this platform. The main goal will be to identify a business opportunity and channel this opportunity to potential interested companies that can collaborate. The role of this IBA will be to launch the opportunity and to create contacts between companies.

IBA20 will also launch their digital platform to support SME internationalisation in a near future. This will be mainly for purposes of information management and information sharing, but also for increasing the visibility of their associate SMEs for potentially interested foreign companies.

Detailed Companies from the sector of IBA5 do not have much information about markets. The market studies expectation of this IBA in the future is to perform detailed market studies mainly to help SMEs with information about distribution chains and contacts. Within those distribution chains the benefit can be to have a study of what is best sold, what types of products, what are the target audiences, etc. However, this IBA currently does not have the necessary funding to achieve this. So, IBA5 plans to apply for external funding in a near future.

Improved IBA6 aims to adjust its activities to the new realities of the markets. The opinion of the communication interviewee is that the future of the IBA will require the use of new IT to improve their strategy communication strategy, in order to transmit an increasingly modern image of the country, of the industrial sector of activity, and to be more "aggressive" in communication.

IBA7 also refers this aspect, by arguing that they need new functionalities in the website, to enable the communication to be done through this channel, and decrease the use of emails.

Focus on new In the IBA8's view, and based on the feedback of their members, the goal in the future is to have markets a mixed logic of markets, i.e. to continue working on "traditional" markets for the sector but also considering emerging and new markets. This will be done by contacting some new markets such as China and Brazil, which are examples of potential destinations for the products of the sector, as well as be present in events and promotional actions of different but related sectors.

Technical actions IBA12 thinks that due to the high costs of trade fairs, companies are increasingly reducing their participation in those events, and the tendency is to focus their attentions in two or three main events per year, as a way to meet all the main buyers and sellers of the sector. Therefore, the idea of this IBA is to focus their attentions in new types of actions, such as design or technical actions, more directed to the product, to strengthen the companies' technical capacity over their own products and to better understand the product they want to sell.

Convergence/ IBA13 provides a different view by arguing that there is a need in IBAs in general for an adaptation to what are the real needs of the companies. They explain that companies only associate to IBAs if there is a clear advantage for them and that, in the future, one of the crucial aspects that can benefit them is the integration and convergence of different business 


\begin{tabular}{ll}
\hline $\begin{array}{l}\text { integration of } \\
\text { business } \\
\text { associations }\end{array}$ & $\begin{array}{l}\text { associations. They think there are many business associations in the country and that there are } \\
\text { too much offer for such a small market, in what regards the promotion of internationalisation } \\
\text { initiatives. This overloads companies with large amounts of information and creates a confusion } \\
\text { in what is the real capacity of each business association to provide a good and quality service. } \\
\text { In the opinion of the interviewee, the aim is "to show an image of an IBA that stands next to the } \\
\text { companies, who does not want to only depend on state subsidies, who do not want to only rely } \\
\text { on European funding, who wants to provide a service in which companies pay to have an } \\
\text { advantage." } \\
\text { IBA14 defends more collaboration between business associations in the future. This can be } \\
\text { achieved by finding synergies and advantages of working together in foreign markets, by sharing } \\
\text { associations } \\
\text { more information, by increasingly working in a network of support to internationalisation. } \\
\text { The interviewee from IBA15 also argues that the collaboration between business associations } \\
\text { will be fundamental to create conditions to look for niche markets, and to gain scale in markets, } \\
\text { by joining capacities. }\end{array}$ \\
\end{tabular}

Looking at Table 4.4, it is clear that the focus of the IBAs' future support to SME internationalisation is based on two important dimensions: IT and collaboration. These two dimensions, as well as all the main findings obtained in this study are discussed in more detail in the next section of Discussion.

\section{Discussion, conclusions and implications}

\subsection{Conceptual map}

The findings reported in the previous section allow to add new knowledge about the institutional network resources and activities used by IBAs to support SME internationalisation. Figure 5.1 results from contextualising the findings of this study and contrasting them with relevant theoretical streams (institutional network perspective of SME internationalisation and business associations), to present a detailed and wider picture about this institutional network influence. Therefore, this map is the result of the abductive reasoning, and is both built on previous theory and collected data for elaborating on theory. 


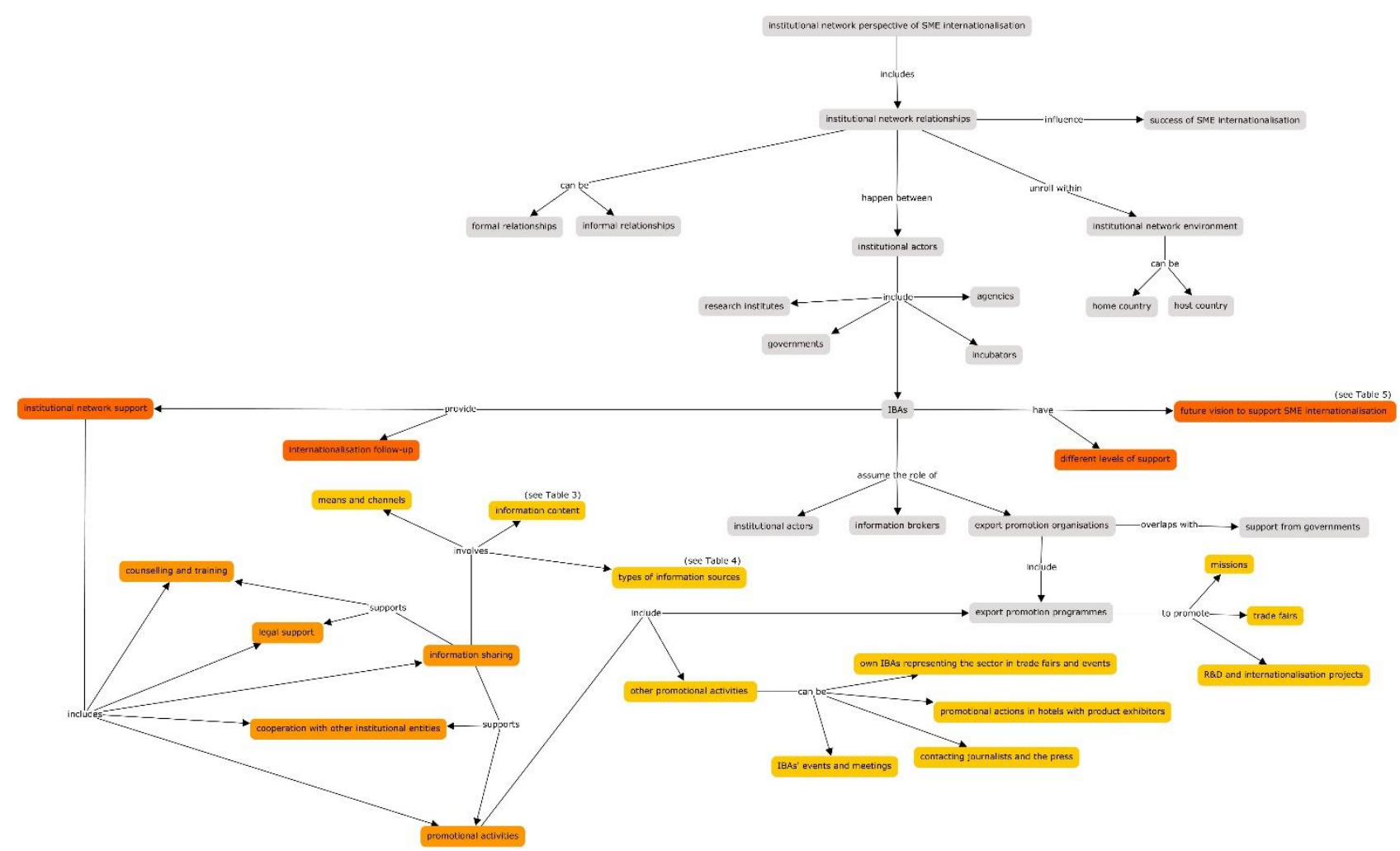

Figure 5.1 - Conceptual map for elaborating theory about the institutional network perspective of SME internationalisation

In this conceptual map of Figure 5.1, the grey parts demonstrate the existing knowledge on the institutional network perspective of SME internationalisation, while the coloured parts represent the extension of theory, from the results obtained in this study. The next sections go more in detail about the discussion of the obtained results.

\subsection{Elaborating the institutional network perspective theory}

\subsubsection{IBAs as institutional network actors and promoters of internationalisation}

The existent knowledge from previous literature on the institutional network perspective in SME internationalisation (Figure 5.1, grey parts) is that SMEs have formal and informal institutional network relationships (Coviello \& Munro, 1997; Gao et al., 2010), with different institutional actors (Child \& Hsieh, 2014; Gardó et al., 2015), in both the home and host countries, and that use the available institutional network resources to improve their internationalisation processes by reducing risks, by increasing the speed of entries into new foreign markets, and by having a more robust knowledge base to operate more efficiently at international levels (Kaur \& Sandhu, 2013; Oparaocha, 2015).

This study supports the findings from Oparaocha (2015), who argues that institutional networks (in general) have a positive impact in SME internationalisation by continuously providing vital resources, such as business contacts, market information, and financial support. Nevertheless, this study elaborates on the institutional network perspective theory and adds an incremental contribution on this matter (Figure 5.1, coloured parts) by adopting a qualitative approach, to cope with the predominance of quantitative studies, and by focusing on the specific role of IBAs, to understand the specific resources and services provided by this institutional actor to support SME internationalisation. 
What we know from the literature of business associations (Figure 5.1, grey parts), is that they are institutional actors (Bennett, 1998; Streeck et al., 2006) and export promotion organisations that use some export promotion programmes from governments to support SME internationalisation (Freixanet, 2012; Wilkinson \& Brouthers, 2006). Findings from the literature show that export promotion programmes can have a positive impact in SME trade promotion (Freixanet, 2012) but, in many cases, there is a lack of awareness of such programmes (European Commission, 2010). Other findings also show the benefits of business association membership for the creation of new collaborations (Costa et al., 2017) and for improving the propensity of SMEs to export (Gashi et al., 2013; Patel-Campillo \& DeLessio-Parson, 2016).

The results obtained in this paper show that, in fact, IBAs use public support and export promotion programmes, to promote some of their initiatives such as trade fairs, trade missions and promotional actions. Nevertheless, this work uncovers other types of support that are not based on these support programmes (Figure 5.1, coloured parts). Specific events, meetings and collaborative workspaces are organised by IBAs in order to address internationalisation issues, and to promote the sharing of knowledge and experiences between associate SMEs and large companies. In some IBAs, it was found that consortiums are formed for applying to new research projects related with internationalisation. In some cases, the IBA adopts a fundamental role of project leader, by establishing new links among its members and by taking the leadership in developing the research proposals.

Another important support provided is related with counselling and different activities on legal support, which is also important to reduce barriers to operate in new foreign markets, also allowing SMEs to internationalise according to the legislation of each market. Some IBAs also give extensive training sessions to SMEs, addressing topics related with marketing, trade fairs, credit insurance, transportation, and other topics related with internationalisation. This type of support reflects the active role of IBAs in helping SMEs in acquiring important knowledge and in identifying suitable partners to approach markets, as well as in preparing them for a proper international expansion.

Therefore, looking at the institutional network influence of IBAs, the main focus is not only for supporting the institutional environment and recognising foreign market opportunities for SMEs, but also for training and providing them with the necessary institutional network resources such as information, contacts, services and conditions for a proper internationalisation. These institutional network resources are obtained internally, by the own studies and initiatives developed by the IBAs, but also externally, through the intensive cooperation with other institutional actors. The different cooperating entities presented in this study act mainly as information sources for IBAs. However, it is natural that, sometimes, competitive environments may exist, together with some overlaps in the roles of the different network players. For example, IBAs and export agencies can provide the same type of information to support the international expansion of SMEs. Another example is two different IBAs that can promote the exact same trade fair to a specific SME. Accordingly, future developments of the institutional network perspective must address these overlaps in terms of the activities promoted and the resources used by the different institutional network actors that support internationalisation processes of SMEs.

\subsubsection{IBAs as information brokers and information managers}

Business associations are also identified in the literature as information brokers for international trade activities (L C Leonidou \& Theodosiou, 2004; Riddle \& Gillespie, 2003). However, there are divergent opinions on the usefulness of the information provided to support internationalisation processes. Some studies find that this information is considered as low value by companies (Leonidas C. Leonidou \& Katsikeas, 1997), while others conclude that this information facilitates 
the obtaining of contacts in foreign markets (P. Walters, 1996), as well as to have access to export laws and to more general information about markets (Riddle \& Gillespie, 2003). Nevertheless, these findings are still insufficient to obtain a clear vision about the information management process of business associations to support internationalisation processes of SMEs.

It is known that business associations provide information services to their members (Boléat, 2003). What we do not know is the detail of the information provided to support SME internationalisation, the sources used to have access to such information, and how this information is shared. Accordingly, new knowledge is also obtained in this study about the specific information content, information sources, and means and channels of information sharing used by IBAs for internationalisation support (Figure 5.1, coloured parts). All the information that is shared by IBAs can allow SMEs to make better decisions and adopt more effective internationalisation strategies. Finally, many institutional entities cooperate with IBAs and act as important information sources, allowing them to have an important network of contacts and network of knowledge, which can also contribute for a better support to the international activities of SMEs.

Diamantopoulos and Souchon (1999) explain that information gathered via different sources differs in terms of its alignment with the different information needs of organisations, and information from different sources varies according to its perceived quality. Souchon et al. (2015) show three different export information acquisition modes: (i) export marketing research, which is formal, systematic and objective and can be carried out both internally and/or externally; (ii) export assistance, which includes market information and guidance on exporting and export marketing; (iii) export market intelligence, which is an informal, experiential export information acquisition mode that comprises obtaining information from network sources, such as customers and distributors, through participation in international trade fairs and shows, or in a more direct way, through foreign visits. According to the authors, these three export information acquisition modes cover a comprehensive array of export information sources. Accordingly, this study also makes an important contribution to the literature of export information generation, showing that IBAs have a prominent role in acquiring export information for their associate SMEs, using the three types of export information acquisition modes.

\subsection{Conceptual model of the institutional network influence of IBAs}

Based on our findings and on previous studies (Oparaocha, 2015), a conceptual model was developed to represent the influence of institutional network resources provided by IBAs, for supporting the internationalisation of SMEs (Figure 5.2). The conceptual framework of Oparaocha (2015) is focused on the general influence of institutional networks in SME internationalisation, and is based on the results of interviews with five SMEs. The model presented in Figure 5.2 results from the findings of the present work and it details the specific influence of one of the institutional actors, the IBAs. This new conceptual model is based on the 20 interviews performed for this study, allowing a more comprehensive view on the phenomenon and the possibility to add new knowledge. 


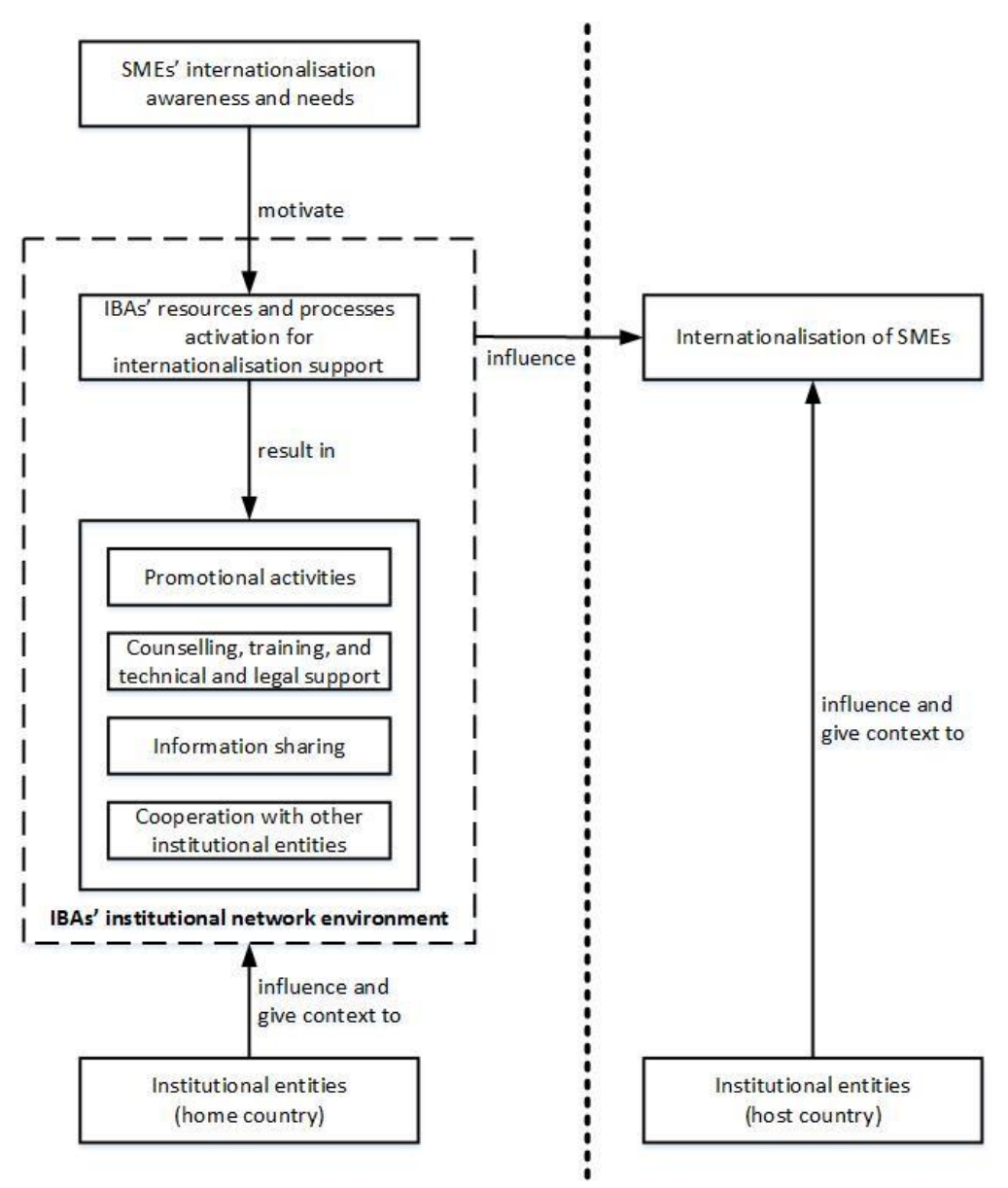

Figure 5.2 - Conceptual model of the institutional network influence of IBAs in internationalisation of SMEs (based on Oparaocha (2015))

The process starts with the SMEs' awareness and needs for internationalisation. Due to the SMEs' limited resources and lack of power to approach markets, the IBAs trigger some support processes and make resources available, to support the SMEs' international activities. IBAs also cooperate and have contacts with other institutional entities, from both the home and the host countries, which influence and give context to support this internationalisation process. Such institutional network support by IBAs is provided through: promotional activities (see section 4.1, IBAs as export promotion organisations); counselling, training, and technical and legal support (see section 4.1, IBAs as export promotion organisations); information sharing (see section 4.1, IBAs as information brokers); and cooperation with other institutional entities (see section 4.1, IBAs as cooperative institutional actors). The support from IBAs can influence the internationalisation of SMEs, by reducing barriers, and by providing the necessary information, contacts and conditions to internationalise.

\subsection{Follow-up process}

Another objective of this study was to understand the IBAs' follow-up process in terms of internationalisation support. Personal contact, instruments such as surveys, and other mechanisms, such as collecting and sharing new information and new contacts, and mobilising local agents to foreign markets, are used to assist SMEs after an internationalisation initiative. Therefore, it seems that most IBAs provide a continuous support for the international operations of SMEs, not only a support at initial stages of internationalisation. Naturally, this support may differ among each IBA. Given the many different types of support and activities developed by each IBA, the nature and effectiveness of the follow-up process can be quite different, but this 
detail is not provided in the present study. However, what was found is that new instruments are needed to improve, for example, the response rate of companies to the surveys sent to the SMEs, and to better perceive the success or failure of the initiatives promoted.

For instance, it is possible to conclude that, regarding the different phases of the internationalisation process (Melén, 2009), IBAs do not have a direct influence in the pre-firm internationalisation phase, as it is up to each company to plan its activities prior to its establishment. However, at this phase, SMEs can resort to their personal networks, where an IBA would appear as a knowledge source, influencing indirectly this phase of internationalisation. In contrast, it is clear that IBAs can influence the initial internationalisation phase of an SME, as demonstrated in the findings of this study. The initiatives, counselling and training provided by IBAs give an initial boost for the international expansion of the associate SMEs. For example, IBA3 reinforces that hundreds of companies started their internationalisation activity with their support. These findings are in accordance with the findings of Wang et al. (2012), who state that firms' internationalisation is facilitated by institutional environments when the institutional entities encourage those firms to start their international activities. Regarding the continued internationalisation phase, the insights obtained for the follow-up process indicate that an IBA can also have influence in this last stage of SME internationalisation.

\subsection{Future vision}

Finally, this paper contributes with new knowledge about the future role of IBAs in supporting SME internationalisation. Collaboration and the use of new IT were referred as the main focal points to improve their support, in a near future. These two dimensions reflect the changes that have been occurring in the business world, where every company and organisation is forced to join efforts with strategic partners, as well as to adopt new IT for their operations, in order to remain competitive. The interviews reveal the importance for IBAs to focus in different types of collaboration to improve the support to SME internationalisation, with entities such as universities and with other IBAs. Collaboration between associate SMEs should also be promoted. Regarding the IT, some IBAs are planning to launch digital platforms to support specific international operations of SMEs. This points out an important development to be studied in detail in further research, which is the use of IT to support SME internationalisation.

These findings can also be contrasted with the study of Costa et al. (2016), who systematically review the literature, examining the role of information, knowledge and collaboration in internationalisation decisions of SMEs. These authors conclude that the lack of information and insufficient knowledge are some of the main obstacles for SMEs to internationalise. Moreover, they suggest that before starting an internationalisation process, SMEs need to seek information and learn from different sources, including the experience gathered in previous internationalisation processes. For that, a collaboration favourable environment should be promoted by the IBA to foster adequate information sharing behaviours. However, in many cases, SMEs still face difficulties in managing information and knowledge from their networks and collaborations, mainly due to the lack of suitable tools and poor information management practices (Costa et al., 2016). The present study suggests that IBAs can have an important facilitating role, by acting as an information manager and promoter of collaborations among their associate companies. With this support from IBAs, SMEs can face their difficulties and have access to three fundamental resources for improving their international activities: information, knowledge, and collaboration. Naturally, these resources can only be obtained, and are only effective, if supported by efficient information, knowledge, and collaboration management processes from IBAs. This discussion adds new elements to the conceptual model presented in Figure 5.2, and enhanced, as represented in Figure 5.3. 


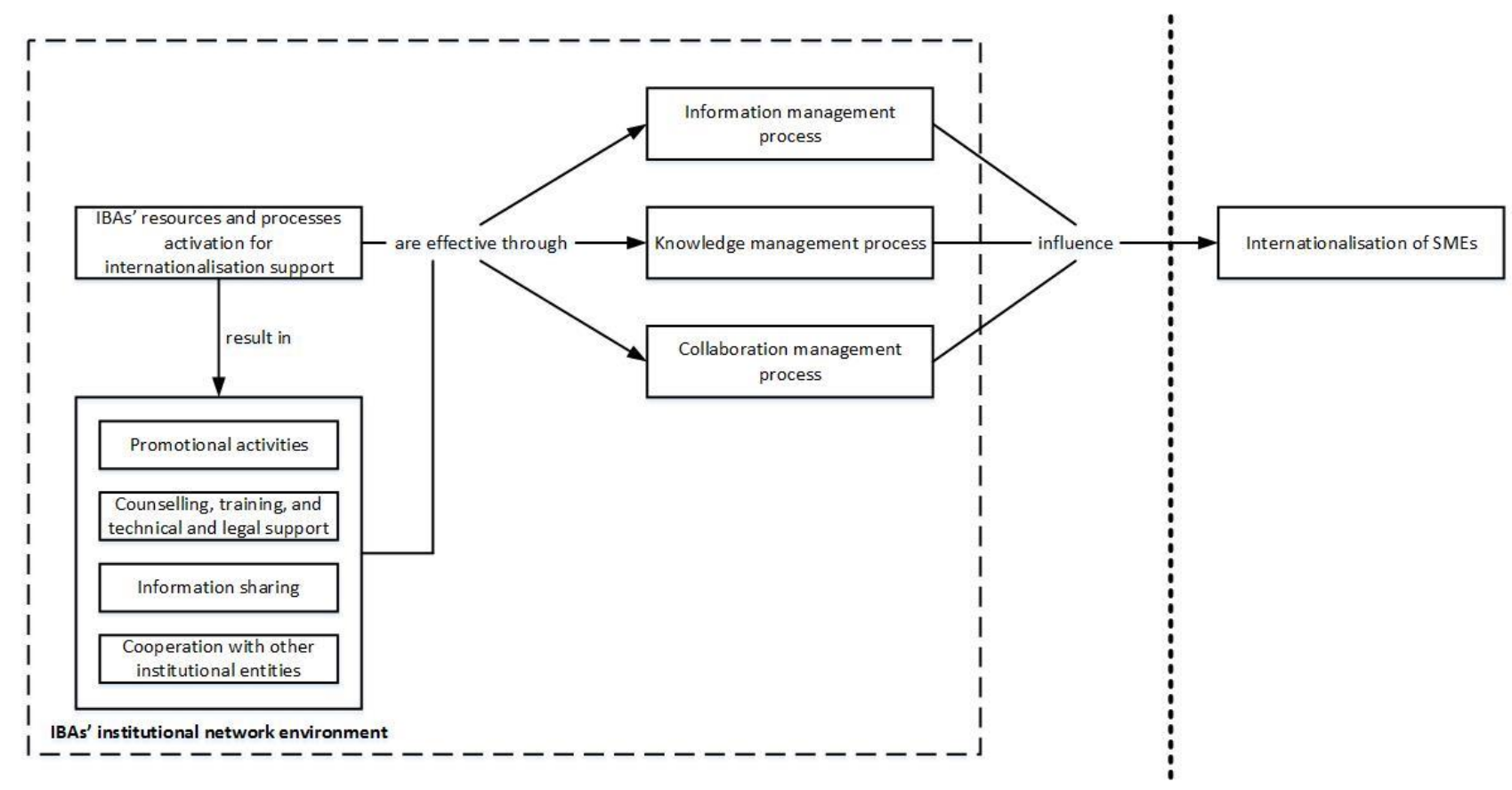

Figure 5.3 - Information, knowledge, and collaboration management processes of IBAs to support SME internationalisation

An important development for the positive impact of IBAs on the internationalisation process is thus the evolution towards a more collaborative network, fostering flows of information and new collaborations between members. This aspect defines another important direction for further developments of this research.

\subsection{Practical implications}

This study shows that IBAs have a wide variety of initiatives and types of internationalisation support for SMEs that are not only based on promotion programmes. However, there is quite often a lack of SME awareness about this support. Thus, the findings of this study can help SMEs to understand the "modus operandi" and the benefits of using the services and initiatives promoted by IBAs. This can also push them to use this support in facing their lack of resources to operate in international markets. Although in a different way, large enterprises can also benefit from IBAs' support. Due to their highly internalised organisation form, market power and high investments abroad, large enterprises do not often use IBAs' assistance for internationalisation processes. Nonetheless, these large and multinational companies can benefit from all the information and the network of contacts of IBAs. Regarding IBAs themselves, the findings of this study can be used to better understand their current position in terms of internationalisation support and think about new ways for improving this support. Additional efforts should also be done by IBAs to increase the awareness among companies about their available services and institutional network resources.

\section{Limitations and further developments}

The adopted methodological approach is qualitative, this normally implying a larger difficulty to obtain a generalisation of the findings. Nevertheless, the main value of qualitative research is the specific description and analysis of the particularity of a specific context, which in this case seemed to be a better option for addressing the exploratory nature of the specific context of 
IBAs. However, future research can be performed in a more quantitative basis to complement the obtained qualitative insights.

Another limitation of this approach is that the participating IBAs are based in different industrial sectors in only one country. Therefore, the findings might not be easy to extend to a specific industry and to other countries. So, more qualitative and quantitative work with larger samples should be done by: (i) performing a similar study and testing the conceptual model in different countries; and (ii) focusing on a specific industrial sector with IBAs from different countries. However, we believe that this study has produced potentially generalizable contributions for European countries where IBAs have similar approaches, such as Spain, France, and Italy. But this remains a topic for future research.

Although using a theoretical sampling strategy, differences among the selected IBAs were verified regarding their focus and level of support in internationalisation. Therefore, the conceptual model may not exactly represent the reality of each IBA.

Due to space limitations, the perspective from SMEs was not introduced and analysed in this study. Instead, we tried to look at the full range of internationalisation-based activities of IBAs and the institutional network resources that are used to support SME internationalisation. In addition, although not specifically focused on the role of IBAs, some previous studies already present this perspective of SMEs about the influence of institutional networks (Gardó et al., 2015; Oparaocha, 2015). Nevertheless, having more data on the SME view is clearly needed for further developments of this work, in order to study if the IBAs' support is viewed as important from both sides of the support.

Finally, future research should possibly address the specific role and influence of other institutional actors that form the institutional setting where SMEs are embedded, such as governments, incubators, agencies for international development, science and technology parks, and other types of business associations. This will certainly lead to a more comprehensive view of institutional networks in SME internationalisation.

\section{References}

Banco de Portugal. (2015). Análise das empresas do setor exportador em portugal (Analysis of companies in the export sector in Portugal). Retrieved from http://www.bportugal.pt/ptPT/ServicosaoPublico/CentraldeBalancos/Biblioteca de Tumbnails/Estudos da CB_22_2015.pdf

Barratt, M., \& Barratt, R. (2011). Exploring internal and external supply chain linkages: Evidence from the field. Journal of Operations Management, 29(5), 514-528. http://doi.org/10.1016/j.jom.2010.11.006

Barratt, M., Choi, T., \& Li, M. (2011). Qualitative case studies in operations management: Trends, research outcomes, and future research implications. Journal of Operations Management, 29(4), 329-342. http://doi.org/10.1016/j.jom.2010.06.002

Behyan, M., Mohamad, O., \& Omar, A. (2015). Influence of internationalization orientation on export performance: In the perspective of Malaysian manufacturing firms. Journal of Business \& Industrial Marketing, 30(1), 83-95. http://doi.org/10.1108/JBIM-05-2012-0091

Bendassolli, P. (2013). Theory building in qualitative research: Reconsidering the problem of induction. Forum Qualitative Sozialforschung / Forum: Qualitative Social Research, 14(1), 1-14. Retrieved from http://nbn-resolving.de/urn:nbn:de:0114-fqs1301258

Bennett, R. (1998). Business associations and their potential contribution to the competitiveness 
of SMEs. Entrepreneurship \& Regional Development, 10(3), 243-260. http://doi.org/10.1080/08985629800000014

Boléat, M. (2003). Managing trade associations. London: Trade Association Forum.

Cannone, G., \& Ughetto, E. (2014). Born globals: A cross-country survey on high-tech start-ups. International Business Review, 23(1), 272-283. http://doi.org/10.1016/j.ibusrev.2013.05.003

Castellacci, F. (2014). Service firms heterogeneity, international collaborations and export participation. Journal of Industry, Competition and Trade, 14(2), 259-285. http://doi.org/10.1007/s10842-013-0153-1

Child, J., \& Hsieh, L. (2014). Decision mode, information and network attachment in the internationalization of SMEs: A configurational and contingency analysis. Journal of World Business, 49(4), 598-610. http://doi.org/10.1016/j.jwb.2013.12.012

Corbin, J., \& Strauss, A. (2015). Basics of qualitative research: Techniques and procedures for developing grounded theory (Fourth). Thousand Oaks, California: Sage Publications.

Costa, E., Soares, A., \& Sousa, J. (2015). A new insight in the SMEs internationalization process. In M. L. Camarinha-Matos, F. Bénaben, \& W. Picard (Eds.), Risks and Resilience of Collaborative Networks: 16th IFIP WG 5.5 Working Conference on Virtual Enterprises, PROVE 2015, Albi, France, October 5-7, 2015 (pp. 398-410). Cham: Springer International Publishing. http://doi.org/10.1007/978-3-319-24141-8_36

Costa, E., Soares, A., \& Sousa, J. (2016). Information, knowledge and collaboration management in the internationalisation of SMEs: A systematic literature review. International Journal of Information Management, 36(4), 557-569. http://doi.org/10.1016/j.ijinfomgt.2016.03.007

Costa, E., Soares, A., Sousa, J., \& Jamil, G. (2017). Information management for network transformation in industrial enterprises associations: The case of the internationalization process. In G. L. Jamil, A. L. Soares, \& C. R. M. Pessoa (Eds.), Handbook of Research on Information Management for Effective Logistics and Supply Chains (pp. 415-436). Hershey, PA: IGI Global. http://doi.org/10.4018/978-1-5225-0973-8.ch022

Coviello, N., \& McAuley, A. (1999). Internationalisation and the smaller firm: A review of contemporary empirical research. MIR: Management International Review, 39(3), 223256.

Coviello, N., \& Munro, H. (1997). Network relationships and the internationalisation process of small software firms. International Business Review, 6(4), 361-386. http://doi.org/10.1016/S0969-5931(97)00010-3

Deloitte. (2015). As associações empresariais do futuro: Evoluir para crescer. Retrieved from http://cip.org.pt/wp-content/uploads/2015/04/CIP_AssociacoesdoFuturo_20150408.pdf

Diamantopoulos, A., \& Souchon, A. (1999). Measuring export information use: Scale development and validation. Journal of Business Research, 46(1), 1-14. http://doi.org/10.1016/S0148-2963(98)00099-X

Eisenhardt, K. (1989). Building theories from case study research. Academy of Management Review, 14(4), 532-550. http://doi.org/10.5465/AMR.1989.4308385

Eisenhardt, K., \& Graebner, M. (2007). Theory building from cases: Opportunities and challenges. Academy of Management Journal, 50(1), 25-32. 
http://doi.org/10.5465/AMJ.2007.24160888

European Commission. (2010). Internationalisation of European SMEs. Survey of the observatory of European SMEs. Retrieved from http://ec.europa.eu/DocsRoom/documents/10008/attachments/1/translations/en/rendi tions/pdf

Freixanet, J. (2012). Export promotion programs: Their impact on companies' internationalization performance and competitiveness. International Business Review, 21(6), 1065-1086. http://doi.org/10.1016/j.ibusrev.2011.12.003

Fries, L. (2008). Boundarians that shape market actors: A review of the literature on business associations. In 24th IMP-conference (pp. 1-17).

Gao, G., Murray, J., Kotabe, M., \& Lu, J. (2010). A "strategy tripod" perspective on export behaviors: Evidence from domestic and foreign firms based in an emerging economy. Journal of International Business Studies, 41(6), 1090-1091. http://doi.org/10.1057/jibs.2010.32

Gardó, T., García, H., \& Descals, A. (2015). Internationalization of SME retailer: Barriers and the role of public support organizations. International Journal of Retail \& Distribution Management, 43(2), 183-200. http://doi.org/10.1108/IJRDM-07-2013-0146

Gashi, P., Hashi, I., \& Pugh, G. (2013). Export behaviour of SMEs in transition countries. Small Business Economics, 42(1), 407-435. http://doi.org/10.1007/s11187-013-9487-7

Golden-Biddle, K., \& Locke, K. (2007). Composing qualitative research (Vol. 2). Thousand Oaks, California: Sage Publications.

Grossman, E., \& Woll, C. (2007). Associations matter: Reconsidering the political strategies of firms in the European Union. In EUSA 10th Biennial International Conference. Montreal, Canada. Retrieved from http://aei.pitt.edu/7891/

Gummesson, E. (2006). Qualitative research in management: Addressing complexity, context and persona. Management Decision, 44(2), 167-179. http://doi.org/10.1108/00251740610650175

Hessels, J., \& Terjesen, S. (2010). Resource dependency and institutional theory perspectives on direct and indirect export choices. Small Business Economics, 34(2), 203-220. http://doi.org/10.1007/s11187-008-9156-4

Ibeh, K., \& Kasem, L. (2011). The network perspective and the internationalization of small and medium sized software firms from Syria. Industrial Marketing Management, 40(3), 358367. http://doi.org/10.1016/j.indmarman.2010.08.004

Javalgi, R., Todd, P., \& Granot, E. (2011). The internationalization of Indian SMEs in B-to-B markets. Journal of Business \& Industrial Marketing, 26(7), 542-548. http://doi.org/10.1108/08858621111162343

Johanson, J., \& Vahlne, J. (1977). The internationalization process of the firm: A model of knowledge development and increasing foreign market commitments. Journal of International Business Studies, 8(1), 23-32. http://doi.org/10.1057/palgrave.jibs.8490676

Johanson, J., \& Vahlne, J. (1990). The mechanism of internationalisation. International Marketing Review, 7(4), 11-24. http://doi.org/10.1108/02651339010137414

Johanson, J., \& Vahlne, J. (2009). The Uppsala internationalization process model revisited: From liability of foreignness to liability of outsidership. Journal of International Business Studies, 
40(9), 1411-1431. http://doi.org/10.1057/jibs.2009.24

Kaur, S., \& Sandhu, M. (2013). Internationalisation of born global firms: Evidence from Malaysia. Journal of the Asia Pacific Economy, 19(1), 101-136. http://doi.org/10.1080/13547860.2013.818426

Ketokivi, M., \& Choi, T. (2014). Renaissance of case research as a scientific method. Journal of Operations Management, 32(5), 232-240. http://doi.org/10.1016/j.jom.2014.03.004

Knight, G., \& Cavusgil, S. (1996). The born global firm: A challenge to traditional internationalisation theory. In T. Cavusgil \& T. Madsen (Eds.), Advances in International Marketing (Vol. 8, pp. 11-26). Bingley: Emerald Group Publishing Limited.

Knight, G., \& Liesch, P. (2016). Internationalization: From incremental to born global. Journal of World Business, 51(1), 93-102. http://doi.org/10.1016/j.jwb.2015.08.011

Lehtinen, U., \& Penttinen, H. (1999). Definition of the internationalization of the firm. In U. Lehtinen \& H. Seristoe (Eds.), Perspectives on Internationalization (pp. 3-19). Helsinki: Helsinki School of Economics and Business Administration.

Leonidou, L., \& Katsikeas, C. (1997). Export information sources: the role of organizational and internationalization influences. Journal of Strategic Marketing, 5(2), 65-87. http://doi.org/10.1080/096525497346802

Leonidou, L., \& Theodosiou, M. (2004). The export marketing information system: An integration of the extant knowledge. Journal of World Business, 39(1), 12-36. http://doi.org/10.1016/j.jwb.2003.08.005

Liesch, P., Håkanson, L., McGaughey, S., Middleton, S., \& Cretchley, J. (2011). The evolution of the international business field: A scientometric investigation of articles published in its premier journal. Scientometrics, 88(1), 17-42. http://doi.org/10.1007/s11192-011-0372-3

Lu, J., \& Beamish, P. (2001). The internationalization and performance of SMEs. Strategic Management Journal, 22(6-7), 565-586. http://doi.org/10.1002/smj.184

Luostarinen, R. (1979). Internationalization of the firm: An empirical study of the internationalization of firms with small and open domestic markets with special emphasis on lateral rigidity as a behavioral characteristic in strategic decision- making. Helsinki: The Helsinki School of Economics.

Makhmadshoev, D., Ibeh, K., \& Crone, M. (2015). Institutional influences on SME exporters under divergent transition paths: Comparative insights from Tajikistan and Kyrgyzstan. International Business Review, 24(6), 1025-1038. http://doi.org/10.1016/j.ibusrev.2015.02.010

Melén, S. (2009). New insights on the internationalisation process of SMEs: A study of foreign market knowledge development. Economic Research Institute. Stockholm School of Economics.

Merriam, S. (1998). Qualitative research and case study applications in education. San Francisco: Jossey-Bass Publishers.

Mikamo, S. (2013). Business associations and politics in the post-EDSA Philippines: Neither oligarchy nor civil society. Philippine Political Science Journal, 34(1), 6-26. http://doi.org/10.1080/01154451.2013.789165

OECD. (2009). Top barriers and drivers to SME internationalisation. Report by the OECD Working Party on SMEs and Entrepreneurship. Retrieved from 
http://strathprints.strath.ac.uk/15845/

Oehme, M., \& Bort, S. (2015). SME internationalization modes in the German biotechnology industry: The influence of imitation, network position, and international experience. Journal of International Business Studies, 46(6), 629-655. http://doi.org/10.1057/jibs.2015.8

Olejnik, E. (2014). International small and medium-sized enterprises: Internationalization patterns, mode changes, configurations and success factors. Trier, Germany: Springer Gabler. http://doi.org/10.1007/978-3-658-04876-1

Oparaocha, G. (2015). SMEs and international entrepreneurship: An institutional network perspective. International Business Review, 24(5), 861-873. http://doi.org/10.1016/j.ibusrev.2015.03.007

Oviatt, B., \& McDougall, P. (1994). Toward a theory of international new ventures. Journal of International Business Studies, 25(1), 45-64. Retrieved from http://www.jstor.org/stable/154851

Patel-Campillo, A., \& DeLessio-Parson, A. (2016). Why types of operations, trade associations, and production trends matter in the geographic branding of an emerging industry. Journal of Wine Research, 27(3), 242-256. http://doi.org/10.1080/09571264.2016.1202218

Pinho, J., \& Pinheiro, M. (2015). Social network analysis and the internationalization of SMEs: Towards a different methodological approach. European Business Review, 27(6), 554-572. http://doi.org/10.1108/EBR-10-2014-0075

Provan, K., \& Kenis, P. (2008). Modes of network governance: Structure, management, and effectiveness. Journal of Public Administration Research and Theory, 18(2), 229-252. http://doi.org/10.1093/jopart/mum015

Riddle, L., \& Gillespie, K. (2003). Information sources for new ventures in the Turkish clothing export industry. Small Business Economics, 20(1), 105-120. http://doi.org/10.1023/A:1020252606058

Schweizer, R. (2012). The internationalization process of SMEs: A muddling-through process. Journal of Business Research, 65(6), 745-751. http://doi.org/10.1016/j.jbusres.2010.12.011

Souchon, A., Dewsnap, B., Durden, G., Axinn, C., \& Holzmüller, H. (2015). Antecedents to export information generation: A cross-national study. International Marketing Review (Vol. 32). http://doi.org/10.1108/IMR-05-2011-0125

Streeck, W., Grote, J., Schneider, V., \& Visser, J. (2006). Governing interests: Business associations facing internationalism. London: Routledge.

Traxler, F., \& Huemer, G. (2007). Handbook of business interest associations, firm size and governance: A comparative analytical approach. London: Routledge.

Vahlne, J., \& Ivarsson, I. (2014). The globalization of Swedish MNEs: Empirical evidence and theoretical explanations. Journal of International Business Studies, 45(3), 227-247. http://doi.org/10.1057/jibs.2013.60

Wach, K. (2014). Theoretical framework of the firm-level internationalisation in business studies. In A. Duréndez \& K. Wach (Eds.), Patterns of Business Internationalisation in Visegrad Countries - In Search for Regional Specifics (pp. 13-30). Universidad Politécnica de Cartagena. 
Walters, P. (1996). International market information infusion: Data acquisition behaviour in Norwegian exporters. International Journal of Information Management, 16(6), 437-444. http://doi.org/10.1016/0268-4012(96)00032-1

Walters, P. G. P. (1993). Export information sources: A study of their usage and utility. International Marketing Review, 1(2), 34-43.

Wang, C., Hong, J., Kafouros, M., \& Boateng, A. (2012). What drives outward FDI of Chinese firms? Testing the explanatory power of three theoretical frameworks. International Business Review, 21(3), 425-438. http://doi.org/10.1016/j.ibusrev.2011.05.004

Wang, J., \& Gooderham, P. (2014). Institutional change and regional development in China: The case of commodity trading markets. Environment and Planning C: Government and Policy, 32(3), 471-490. http://doi.org/10.1068/c11254b

Wheeldon, J., \& Faubert, J. (2009). Framing experience: Concept maps, mind maps, and data collection in qualitative research. International Journal of Qualitative Methods, 8(3), 6883. http://doi.org/10.1177/160940690900800307

Whetten, D. (1989). What constitutes a theoretical contribution? Academy of Management Review, 14(4), 490-495.

Wilkinson, T., \& Brouthers, L. (2006). Trade promotion and SME export performance. International Business Review, 15(3), 233-252. http://doi.org/10.1016/j.ibusrev.2006.03.001

Xie, Y., \& Amine, L. (2009). Social networks and the internationalization of Chinese entrepreneurs. Global Business and Organizational Excellence, 29(1), 61-78. http://doi.org/10.1002/joe.20299

Yin, R. (2009). Case study research: Design and methods. Applied Social Research Methods Series (Fourth Edi, Vol. 5). Thousand Oaks, California: Sage Publications. 